\title{
RECENT ADVANCES IN RADIO ENGINEERING
}

\author{
Radio Meeting in Washington
}

\begin{abstract}
A JOINT meeting of the Institute of Radio Engineers and the International Scientific Radio Union (American Section) was held at Washington, D.C., during April 28-29, 1939. Trenty-four papers on the moro fundamental aspects of radio communication were presented.
\end{abstract}

A paper of particular interest, by D. R. Goddard, $\mathrm{RCA}$ Communications, Inc., reported reception at Riverhead (Long Island), N.Y., of British television transmissions on 41.5 and 45.0 megacyeles from Alexandra Palace, London. The British afternoon programmes, between 9.30 a.m. and 11.30 a.m. New York time, could be received at times during certain winter months with some clarity. The author showed motion picture reproductions of images received on a number of occasions; both clear and distorted. Multiple path transmission was believed to bo responsible for some of the distortion. In the past few years, the latest date for which reception is possible has been steadily receding from March through February to January, and it seems probablo that next winter no reception at Riverhead of these signals will be possible after December 31 .

Prof. Leon Brillouin of the Collège de France presented a comprehensive theoretical discussion of the transmission of electromagnetic waves in hollow conductor pipes, and reported confirmatory experimental work. Pipes of elliptical cross-section have been investigated, as well as those of square crosssection. Acoustic analogies, as discussed by MI. Brillouin (J. Phys., 1906), havo been found of material assistance in these studies. An application of this investigation is to the design of tuning units of small attentuation for very high frequencies.

W. E. Jackson, of tho U.S. Civil Aeronautics Authority, described the use of ultra-high frequencies, as 63 megacycles, in radio aids to air navigation. These frequencies reduce imultiple course indications, and are particularly suitable for aircraft application where usual horizon limitations do not apply.

H. T. Stetson, of the Massachusetts Institute of Technology, reported corroboration of a lunar effect of radio transmission which he discovered and pub. lished several years ago. A large number of observa. tions have been examined, and appear to yield fairly consistent results among themselves, indicating increased field strengths as the moon nears the meridian. Reference was made to a discussion of lunar effects by Appleton (Nature, July 9, 1938, p. 71).

B. Trevor, of RCA Communications, Inc., reported measurements of attenuation at 500 megacycles and 250 megacycles through 500 feet of woods and underbrush, also over low scrub pines.

J. T. Henderson, J. W. Bell and H. IR. Smyth, of the National Research Council of Canada, described a 12-inch cathode-ray direction finder and its application to determine the direction of atmospheries. A cathode-ray direction finder equipment, received some time ago from the Radio Research Board of Great Britain, was used at Ottawa. At Forrest, Manitoba, a newer direction finder, designed and constructed by the authors, was used, and avoided defects found in tho older instrument. Observers in Florida and Puerto Rico co-operated, particularly in studies of hurricano disturbances. Thile it is not yet possiblo to locate storms by these directional observations of atmospherics, before the Weather Bureau locates them by acroplane observations, such early location of storms is an object of the work.

S. S. Kirby and F. R. Gracely, of the U.S. National Bureau of Standards, reported comparisons of signals at broadcast frequencies received at Washington from Buenos Aires with signals received from Rennes, France, and other European stations. The measurements havo usually been mado from 1 to 3 a.m. Washington time. The South American path averages about twenty times as good as the European path, both as to averago field intensity and as to range of night-to-night variations of field intensity. The observed transmitting conditions were compared with co-existing magnetic disturbances, and it appears that the poor transmitting conditions on the northern path (auroral zone) may persist several days after the magnetic disturbance has ceased, the day following cessation of the magnetic disturbance often being particularly bad.

Ralph Stair and IV. IV. Coblentz, of the U.S. National Bureau of Standards, described a precision instrument sent aloft with balloons for observing and reporting to the ground the distribution of ozone in the stratosphere. There is used a precision method of making such measurements by measuring the change in spectral distribution of uitra-violet solar radiation at different heights as the balloons rise. Measurements of intensity in the ultra-violet are made by a special cadmium photo-electric cell which covers the range from about $2800 \mathrm{~A}$. to $3300 \mathrm{~A}$., and these are transmitted to the ground by a small radio transmitter including a relaxation oscillator. The instrument has been described in the March 1939 Bureau of Standards Journal of Research. It has been sent up to heights of $27 \mathrm{~km}$.; about two-thirds of the total ozone lies below this height. Maximum ozone content has been found at heights of about $25 \mathrm{~km}$.

Andrew Alford, of Mackay Radio and Telegraph Co., reported studies at high frequencies of char. acteristics of antenna arrays. Ho described marked differences in the phase of signals received over relatively long distances from two similar transmitting antenne, only a few hundred feet apart, operating at the same time on the same frequency. The keying of the two transmitters was interlocked, and the signals wero received and compared at the receiving station as to phase and intensity on a cathode-ray oscillograph. It appears that the construction of a directive transmitting array to obtain gain may fail of its purpose if the signals from different antennx arrive out of phase, due to transmission over different paths. Proper phasing of inputs at the transmitting array may be an effective control, to get proper co-operation between the different antennx.

R. C. Colwell and A. W. Friend, of the University of West Virginia, reported studies of tropospheric 
reflections at about $2,400 \mathrm{kc}$. Preliminary tests in conjunction with data from simultaneous aeroplane flights indicate direct connexion with temperature and humidity variations in the troposphere, as reflection at a temperature front. These reflections may be susceptible of use for weather prediction, both for primary data in localities where noither aeroplane flights nor radio sonde ascents are available, and also as secondary data to interpolato between such regular flights and ascents at established stations (seo NATURE, July 1, 1939, p. 31).

L. V. Berkner, of the Carnegie Institution of Washington, who has just returned from an extended visit to Australia, described foreign installations and technique for ionospheric exploration. Observations at the Watheroo (Western Australia) station of the Carnegie Institution were discussed in particular detail, especially with reference to the formation of the $E$-region, and there was pointed out the importance of co-ordination of ionospheric measurements from a number of stations widely separated over the earth, and the extensions of ionospheric knowledge already so obtained.

N. Smith and A. S. Taylor, of the U.S. National Bureau of Standards, described a project now under way to predict monthly average ionospheric characteristics and maximum usable frequencies for undisturbed days, for several months in advance. Such predictions are now being published each month in the Proceedings of the Institute of Radio Engineers. These predictions are related to sunspot numbers.

J. A. Pierce and H. R. Mimno, of Harvard University, reported on the reception of radio echoes from distant ionosphere irregularities. Studies of numerous reflection patterns strongly indicate that the delayed echoes are returned from regions where there is a marked curvature of the $F$-layer, as at the edge of the sunlit zone. There may be successive reflections between the $E$ and $F$ layers.

Other papers covered a comprehensive study of the characteristics of noise in radio reception, a field strength survey on $52 \cdot 75$ megacycles in the Now York area, transmission on 7 megacycles between Los Angeles and San Francisco, a comparison of shunt and series excitation of a 0.55 wave-length uniform cross-section broadcast vertical radiator, inductive output tubes, shiclding of radio-frequency ammeters, and additional ionosphero studies.

The meeting was preceded and followed by a number of informal round-table discussions of groups specialized in certain aspects of ionosphere and transmission phenomena. It is expected that a number of the papers presented will bo published in the Proceedings of the Institute of Radio Engineers.

\section{BEIT MEMORIAL FELLOWSHIPS FOR MEDICAL RESEARCH}

\begin{abstract}
A
MEETING of the trustees of the Beit Memorial Fellowships for Medical Research, Sir Alfred Beit, the Earl of Onslow, Lord Harlech, Lord Rayleigh, Lord Macmillan of Aberfeldy, Prof. T. R. Elliott and Dr. H. L. Eason, was held on July 19, 1939. They received with regret the resignation from the advisory board of Sir F. Gowland Hopkins, who throughout the long period of twenty-five years has given wise counsel at the meetings of the Board and in his Biochemical Department at Cambridge has directed the research studies of perhaps a greater proportion of those elected to Beit Fellowships than any other head of a department has done. They also regretted the resignation of Sir Patrick Laidlaw after eight years of keenly attentive work. These vacancies were filled by the appointment to the Board of Prof. R. A. Peters, Whitley professor of biochemistry, University of Oxford, and of Dr. Paul Fildes, bacteriologist on the scientific staff of the Medical Research Council.

Former holders of fellowships have recently received appointments as follows : C. H. O'Donoghue (fellow 1912-13) to be professor of zoology at the University of Reading ; J. T. Irving (fellow 1926-28), to be professor of physiology in the University of Cape Town, South Africa; G. F. Marrian (fellow $1927-30)$ to be professor of chemistry in relation to medicine in the University of Edinburgh; F. H. Smirk (fellow 1930-34), to be professor of medicine in the University of Otago, New Zealand; and H. P. Himsworth (fellow 1932-35), to bo professor of medicine in the University of London and director of the Medical Unit at University College Hospital.

It was in 1910 that the first Beit fellow, now Sir Thomas Lewis, was elected, and last year's election
\end{abstract}

in 1938 brought the total of all fellows elected to exactly 200. IVomen are eligiblo and have been elected from 1910 onwards, their total being 30 out of the 200 . Of the 170 men, 6 have been elected to the fellowship of the Royal Society, and no fewer than 34 have already been appointed to university professorships, of which 5 wero in physiology, 5 in pharma. cology, 5 in medicine and 9 in chemistry or biochemistry. Eight of theso past Beit fellows hold professorial chairs in the Dominions over-seas. None of the women has yet been promoted to a university professorship, though at least six of them are doing work of much distinction and one has for some years been director of an important research laboratory. The opportunities for a woman to obtain a university chair in a scientific subject are still restricted.

Though the Beit fellows have come from all parts of the British Empire and have afterwards gone to laboratory posts all over the world, in their choice of a place of research during their fellowships they have tended to group themselves at three main centres. Out of the total 200, the laboratories at Cambridgo have held 55, and 29 of these were personally directed by Sir Gowland Hopkins in the great Biochemical School that ho developed in the Dunn Laboratories immediately after their opening in 1925. University College and University College Hospital in London together have provided oppor. tunities for the work of 39 . The Lister Institute of Preventive Medicine has accepted 35 . The trustees have expressed their gratitude to the directors of these and of the other laboratories in Great Britain and elsewhere who have not only guided the work of the Beit fellows attached to them, but also provided the laboratory cost of that work. 